\title{
PENGENDALIAN DORONGAN SEKSUAL MELALUI PENINGKATAN PERAN ORANG TUA DAN AKTIVITAS SANTRIWATI
}

\section{CONTROL OF SEXUAL DRIVE THROUGH INCREASING PARENTS ROLE AND ACTIVITY OF ISLAMIC BOARDING SCHOOLS STUDENT}

\author{
Samara Rahma Dania ${ }^{1}$, Lutfi Agus Salim ${ }^{2}$ \\ ${ }^{1,2}$ Departemen Biostatistika dan Kependudukan \\ Fakultas Kesehatan Masyarakat Universitas Airlangga \\ Jl. Mulyorejo Kampus C Unair Surabaya, Jawa Timur 60115, Indonesia \\ Alamat korespondensi: Samara Rahma Dania \\ E-mail: samaradania25@gmail.com
}

\begin{abstract}
One of adolescence's problems is uncontrolable sexual drive. It was expected that the students of Islamic boarding school have a sexual driving better than students of common school. But, sexuality problem among boarding school's student is similar with student in common school. Good sexual driving can protect the students from negative impacts of sexual activity. Sexual driving is influenced by parent's role and student activity. This study aimed to analyse the relationship between parent's role and student activity with sexual driving of female student in islamic boarding school in Sukoharjo City. The research was taken on April, 2019. The subjects were 107 students in the age of 10-18 who study at Madrasah Aliyah (MA) Pondok Pesantren X and Y, Kabupaten Sukoharjo. Research method is cross-sectional. Sampling technique was stratified random sampling, whereas data collection technique is interview using questionnaire. The data were a analyzed with chi-square ( $p$ value $<0,005)$. The result showed that parent's role has significant relationship with sexual driving ( $p$ value $<0,005$ ), whereas activity do not have relationship with sexual driving ( $p$ value $>0,05$ ). Parent's role was giving direction to their children to have good behavior. Student who has good faith will avoid something that prohibited in Islam. Although student of Islamic Boarding School has leisure time, regulation of Islamic boarding school makes them are avoided from negative sexual activity.
\end{abstract}

Keywords: sexual drive, parent's role, activity, female student

\begin{abstract}
ABSTRAK
Salah satu problematika remaja adalah dorongan seksual yang tidak terkelola dengan baik. Santri yang bersekolah di pesantren seharusnya memiliki dorongan seksual yang lebih terkontrol daripada mereka yang bersekolah di sekolah umum. Namun, permasalahan seksualitas remaja pesantren ternyata tak jauh berbeda dengan permasalahan remaja pada umumnya. Pengendalian yang baik membuat remaja menghindari perilaku negatif seperti perilaku seksual pra nikah. Penelitian ini bertujuan untuk menganalisis hubungan antara peran orang tua dan aktivitas dengan pengendalian dorongan seksual santriwati di pesantren di Kabupaten Sukoharjo. Waktu penelitian dilakukan pada bulan April 2019. Lokasi penelitian dilakukan di Madrasah Aliyah (MA) Pondok Pesantren X dan Y, Kabupaten Sukoharjo yang berusia 10-18 tahun sebanyak 107 santriwati. Desain penelitian yang dilakukan adalah cross sectional. Sampel diambil dengan teknik stratified random sampling, sedangkan data dikumpulkan melalui wawancara dengan kuesioner. Analisis data menggunakan chi-square dengan menggunakan tingkat kemaknaan $95 \%(\alpha=0,05)$. Uji statistik menunjukkan bahwa variabel peran orang tua memiliki hubungan dengan pengendalian dorongan seksual $(\mathrm{p}<0,05)$, sedangkan aktivitas tidak memiliki hubungan dengan pengendalian dorongan seksual $(p>0,05)$. Orang tua berperan untuk mengarahkan anaknya untuk berperilaku yang baik. Santriwati yang memiliki iman kuat akan memiliki akhlak yang baik dan menjauhi larangan agama. Meskipun santri memiliki waktu luang, peraturan pesantren yang ketat membuat mereka terhindar dari aktivitas negatif.
\end{abstract}

Kata kunci: pengendalian dorongan seksual, peran orang tua, aktivitas, santriwati 


\section{PENDAHULUAN}

World Health Organization (WHO) menyatakan bahwa remaja merupakan mereka yang berada pada interval usia 10-19 tahun. Masa tersebut merupakan saat kondisi fisik, psikologis maupun intelektual seseorang sedang tumbuh dan berkembang dengan pesat (WHO, 2018b).

Remaja adalah generasi yang berperan dalam membangun masa depan keluarga, bangsa, dan negara. Hal ini dikarenakan pemuda di masa sekarang adalah mereka yang kelak akan memimpin bangsa dan negara suatu saat nanti (Nafis, 2011). Terlebih pada remaja putri, jika mereka hancur maka generasi masa depan akan ikut hancur. Begitu pun jika mereka baik, maka generasi selanjutnya juga akan baik (El-Shafa, 2014). Remaja putri suatu saat akan menjadi sekolah pertama bagi anak-anaknya. Baik dan buruknya generasi Indonesia tidak luput dari ajaran yang disampaikan para ibu. Maka, hal ini semakin meyakinkan bahwa wanita adalah tiang negara (Supriyadi, 2017).

Terdapat sebuah masalah yang kerap terjadi pada remaja, yaitu mereka yang kurang mampu mengelola hasrat atau dorongan seksual. Setiap manusia yang normal pasti memiliki dorongan seksual, karena hal ini adalah hal yang fitrah bagi manusia yang dianugerahkan oleh Allah. Jika ketahanan diri seseorang melemah, maka dorongan seksual ini dapat mengarah pada perbuatan negatif (Haryanto, 2015).

Di Indonesia, saat ini remaja berada dalam keadaan yang memprihatinkan (Nafis, 2011). Pada tahun 2017, terdapat $18,9 \%$ remaja lakilaki dan perempuan di Indonesia yang berusia 15-17 tahun pernah melakukan hubungan seksual (BKKBN, 2017). Fakta lain menunjukkan bahwa sebanyak 33,3\% remaja berusia 10-14 tahun di Jawa Tengah sudah mulai berpacaran. Persentase ini cukup besar sehingga Jawa Tengah menduduki peringkat keenam di Indonesia (BKKBN, 2012). Hal ini perlu diwaspadai karena jika semakin mudah seseorang dalam berpacaran, maka potensi untuk melakukan hubungan seksual juga akan semakin besar (Wijayanti \& Robi'i, 2017)

Mencetak generasi muda yang baik bukanlah hal mudah, karena banyaknya faktor negatif yang mempengaruhi perilaku remaja saat ini. Faktor yang mempengaruhi persoalan remaja berasal dari dalam dan luar diri remaja. Faktor eksternal berasal dari lingkungan, keluarga, kondisi, serta kemajuan sains dan teknologi. Sedangkan faktor internal adalah kondisi psikologis remaja yang masih labil dan pengetahuan agama yang kurang baik (Nafis, 2011).

Setiap orang tua tentunya ingin memiliki anak remaja yang memiliki perilaku dan sikap yang baik. Mendidik anak dengan agama sejak dini adalah salah satu metode yang dapat dilakukan (Firdausita, 2017). Remaja yang beriman kuat maka akan berpotensi untuk berakhlak baik dan menghindari melakukan perbuatan yang dilarang oleh agama. Lembaga pendidikan merupakan salah satu alternatif yang baik guna mendidik remaja agar sesuai dengan nilai dan norma agama (Surbakti, 2009).

Pesantren adalah lembaga pendidikan yang berlandaskan ajaran agama Islam. Santri mempelajari agama yang kelak digunakan dalam landasan untuk berperilaku (Kompri, 2018). Pada tahun 2015, terdapat sebanyak 587.211 pesantren yang berada di setiap provinsi di Indonesia (EMIS, 2016). Pesantren memiliki beberapa peran, diantaranya adalah untuk mendidik generasi muda, berdakwah, dan menanamkan akhlak yang baik dan membentuk pemuda berkualitas dalam hal spiritualitas, intelektualias, memiliki ketrampilan, dan mau menerima perubahan zaman (Kompri, 2018).

Seseorang yang bersekolah di sekolah berbasis agama memiliki dorongan seksual yang lebih terkontrol daripada mereka yang bersekolah di sekolah umum (Kurniawati, 2018). Namun, permasalahan seksualitas remaja pesantren yang memiliki basis agama baik ternyata tak jauh berbeda dengan permasalahan remaja pada umumnya. Santri juga dapat berpacaran meskipun dilakukan dengan sembunyi-sembunyi ketika di pesantren (Towaf, 2008). Santri sebaiknya memiliki pengendalian diri, salah satunya agar tidak melanggar tata tertib di pesantren (Pujawati, 2016). Pengendalian diri adalah suatu hal yang mampu mengendalikan dan mengarahkan perilaku seseorang (Aviyah \& Farid, 2014). Sedangkan mengendalikan hasrat seksual adalah 
suatu metode guna mengendalikan diri dalam mengelola perasaan dengan orang lain secara seksual (BKKBN, 2012). Jika remaja dapat mengendalikan diri dengan baik, maka ia dapat terhindar dari perilaku negatif seperti aktivitas seksual pra nikah (Khairunnisa, 2013).

Pengendalian dorongan seksual dapat dipengaruhi oleh peran orag tua dan aktivitas santri. Penggunaan waktu adalah hal yang perlu diperhatikan karena jumlah waktu yang dihabiskan untuk berbagai macam kegiatan itu dapat mencegah terjadinya masalah pada remaja (Barnes et al., 2007). Sebuah penelitian di Michigan Tenggara menunjukkan bahwa dengan menyibukkan remaja dengan hal produktif dapat mengurangi waktu remaja untuk berpacaran (Kao \& Salerno, 2014). Sekolah hendaknya dapat menambah daftar kegiatan positif seperti olahraga, kegiatan keagamaan, dan ekstrakurikuler. Sekolah juga harus memantau kehadiran murid supaya disiplin mengikuti kegiatan serta menghukum jika ada yang tidak mematuhi peraturan (Kurniawati, 2018). Akan tetapi, pesantren dengan peraturan yang sedemikian ketat ternyata masih terdapat santri yang menyalurkan dorongan seksual ke arah negatif (Fitriyah, Indriani dan Sulistyorini, 2013).

Peraturan pesantren dimana santri tinggal berpisah dengan orang tua bisa menjadi penyebab kurangnya komunikasi antar keduanya. Ketidaksiapan orang tua dalam menyikapi seksualitas anak dapat menyebabkan berbagai problematika pada remaja (Haryanto, 2015). Orang tua hendaknya tidak merasa tabu dan malu untuk membicarakan seksualitas dengan anak remajanya. Hal ini diperlukan agar anak dapat memperoleh informasi yang dapat dipertanggung jawabkan (Khairunnisa, 2013).

Peneliti tertarik meneliti pengendalian dorongan seksual remaja putri di Pondok Pesantren $\mathrm{X}$ dan Pondok $\mathrm{Y}$ yang terletak di Kabupaten Sukoharjo. Tujuan penelitian ini adalah untuk menganalisis hubungan antara peran orang tua dan aktivitas dengan pengendalian dorongan seksual remaja putri di pesantren. Jawa Tengah adalah provinsi dengan jumlah pesantren terbanyak keempat di Indonesia dengan jumlah pesantren sebanyak 4.685 buah, sedangkan
Sukoharjo merupakan sebuah kabupaten dengan 840 pesantren dan 7.722 orang santri pada tahun 2015 (EMIS, 2016). Penelitian di Kecamatan Kartasura, Kabupaten Sukoharjo menunjukkan sebanyak $82,7 \%$ keluarga mendukung remaja untuk melakukan aktivitas pacaran dan sebanyak $32,5 \%$ remaja melakukan sikap seksual yang negatif (Wijayanti \& Robi'i, 2017). Perkembangan jumlah pesantren yang pesat dan banyaknya keluarga yang mendukung remaja berpacaran menjadikan pesantren di kabupaten Sukoharjo menarik untuk diteliti. Penelitian ini diharapkan mampu memberikan masukan bagi kebijakan pesantren agar mampu mengelola dorongan seksual yang timbul pada santriwati dengan baik.

\section{METODE PENELITIAN}

Penelitian ini bersifat analitik dengan tujuan untuk menganalisis hubungan antara peran orang tua dan aktivitas dengan pengendalian dorongan seksual santriwati di pesantren di Kabupaten Sukoharjo. Pendekatan yang dilakukan menggunakan observasional karena melakukan pengamatan terhadap data yang telah dikumpulkan. Desain penelitian yang dilakukan adalah cross sectional, karena peneliti mengukur variabel bebas dan tergantung pada sampel secara bersamaan.

Populasi penelitian yaitu santriwati Madrasah Aliyah (MA) Pondok Pesantren X dan Y pada tahun 2019. Subyek penelitian diterima untuk dijadikan sampel penelitian jika memenuhi kriteria inklusi, antara lain berusia 10-19 tahun, belum menikah, dan bersedia menjadi sampel penelitian.

Sampel sebanyak 107 santriwati diambil dengan teknik pengambilan sampel stratified random sampling. Teknik ini dipilih karena dua pesantren yang digunakan untuk penelitian memiliki ciri khas yang berbeda. Bangunan pesantren $\mathrm{X}$ bersifat terbuka sehingga memiliki kemungkinan besar terjadinya pertemuan antara santriwan dan santriwati, sedangkan pesantren $\mathrm{Y}$ memiliki bangunan yang lebih rapat sehingga memiliki kemungkinan kecil terjadinya pertemuan antara santriwan dan santriwati. Dalam mengumpulkan data primer, 
peneliti menggunakan metode wawancara dengan kuesioner. Data lalu diolah menggunakan software statistik. Analisis data menggunakan chi-square dengan tingkat kemaknaan $\alpha=0,05$.

\section{HASIL PENELITIAN}

\section{Karakteristik Umum Responden}

Tabel 1 menjelaskan mengenai karakteristik santriwati. Hasil penelitian menunjukkan bahwa dari 107 santriwati, paling banyak adalah yang berusia 17 tahun $(43,0 \%)$. Responden memiliki lama mondok yang bervariasi. Sebagian besar mengaku telah mondok dalam waktu yang lama yaitu $50-59$ bulan $(61 \%)$

\section{Pengendalian Dorongan Seksual Santriwati}

Penelitian dilakukan pada 2 pesantren dengan karakteristik yang berbeda. Pesantren $\mathrm{X}$ dengan bangunan bersifat terbuka memiliki kemungkinan besar terjadinya pertemuan antara santriwan dan santriwati, sedangkan pesantren $\mathrm{Y}$ dengan bangunan yang lebih rapat memiliki kemungkinan kecil terjadinya pertemuan antara santriwan dan santriwati.

Tabel 2 menggambarkan perbedaan aktivitas seksual yang dilakukan santriwati pada pesantren $\mathrm{X}$ dan Y. Santriwati di pesantren Y memiliki dorongan seksual yang lebih tinggi daripada pesantren $X$.

Tabel 1. Distribusi Frekuensi Berdasarkan Karakteristik Responden

\begin{tabular}{lcc}
\hline & Besar $\mathbf{n}=\mathbf{1 0 7}$ & $\mathbf{\%}$ \\
\hline Usia Responden & & \\
16 tahun & 34 & 31,8 \\
17 tahun & 46 & 43,0 \\
18 tahun & 27 & 25,2 \\
Lama Mondok & & \\
$10-19$ bulan & 1 & 0,9 \\
$20-29$ bulan & 10 & 9,3 \\
$30-39$ bulan & 34 & 32 \\
$40-49$ bulan & 1 & 0,9 \\
$50-59$ bulan & 61 & 57 \\
\hline
\end{tabular}

Tabel 2. Perbedaan Aktivitas Seksual yang Pernah dilakukan Santriwati Selama Mondok Menurut Jenis Pesantren

\begin{tabular}{|c|c|c|c|c|}
\hline \multirow{2}{*}{$\begin{array}{c}\text { Aktivitas } \\
\text { Seksual }\end{array}$} & \multicolumn{2}{|c|}{ Pesantren X } & \multicolumn{2}{|c|}{ Pesantren Y } \\
\hline & $\begin{array}{c}\text { Besar } \\
n=56\end{array}$ & $\%$ & $\begin{array}{l}\text { Besar } \\
n=51\end{array}$ & $\%$ \\
\hline \multicolumn{5}{|l|}{ Berfantasi } \\
\hline $\mathrm{Ya}$ & 38 & 67,9 & 39 & 76,5 \\
\hline Tidak & 18 & 32,1 & 12 & 23,5 \\
\hline \multicolumn{5}{|l|}{ Chatting } \\
\hline $\mathrm{Ya}$ & 50 & 89,3 & 37 & 72,5 \\
\hline Tidak & 6 & 10,7 & 14 & 27,5 \\
\hline \multicolumn{5}{|c|}{ Jalan berdua } \\
\hline $\mathrm{Ya}$ & 10 & 17,9 & 19 & 37,3 \\
\hline Tidak & 46 & 82,1 & 32 & 62,7 \\
\hline \multicolumn{5}{|c|}{ Berpegangan tangan } \\
\hline $\mathrm{Ya}$ & 3 & 5,4 & 9 & 17,6 \\
\hline Tidak & 53 & 94,6 & 42 & 82,4 \\
\hline \multicolumn{5}{|l|}{ Mengelus } \\
\hline $\mathrm{Ya}$ & 1 & 1,8 & 4 & 7,8 \\
\hline Tidak & 55 & 98,2 & 47 & 92,2 \\
\hline \multicolumn{5}{|l|}{ Merangkul } \\
\hline $\mathrm{Ya}$ & 4 & 7,1 & 9 & 17,6 \\
\hline Tidak & 52 & 92,9 & 42 & 82,4 \\
\hline \multicolumn{5}{|l|}{ Memeluk } \\
\hline $\mathrm{Ya}$ & 2 & 3,6 & 3 & 5,9 \\
\hline Tidak & 54 & 96,4 & 48 & 94,1 \\
\hline \multicolumn{5}{|l|}{ Cium pipi } \\
\hline $\mathrm{Ya}$ & 0 & 0 & 2 & 3,9 \\
\hline Tidak & 56 & 100 & 49 & 96,1 \\
\hline \multicolumn{5}{|c|}{ Berhubungan seksual } \\
\hline Ya & 0 & 0 & 2 & 3,9 \\
\hline Tidak & 56 & 100 & 49 & 96,1 \\
\hline
\end{tabular}

Santriwati di pesantren Y melakukan aktivitas berfantasi $(76,5 \%)$, jalan berdua $(37,3 \%)$, berpegangan tangan $(17,6 \%)$, mengelus (7,8\%), merangkul (17,6\%), memeluk $(5,9 \%)$, cium pipi $(3,9 \%)$, dan berhubungan seksual (3,9\%) lebih besar daripada santriwati di pesantren $X$ dengan persentase berfantasi $(67,9 \%)$, jalan berdua $(17,9 \%)$, berpegangan tangan $(5,4 \%)$, mengelus $(1,8 \%)$, merangkul $(7,1 \%)$, memeluk $(3,6 \%)$, cium pipi $(0 \%)$, dan berhubungan seksual $(0 \%)$. 
Tabel 3. Pengalaman Berpacaran Santriwati Selama di Pesantren

\begin{tabular}{lcc}
\hline Pengalaman Berpacaran & $\begin{array}{c}\text { Besar } \\
\mathbf{n = 1 0 7}\end{array}$ & $\mathbf{\%}$ \\
\hline Pernah berpacaran & 15 & 14,0 \\
Tidak pernah berpacaran & 92 & 86,0 \\
Total & 107 & 100,0 \\
\hline
\end{tabular}

Pada Tabel 3 menunjukkan pengalaman berpacaran santriwati. Sebagian besar santri tidak pernah berpacaran $(86 \%)$ selama bersekolah di pesantren.

\section{Hubungan antara Aktivitas, Peran Orang Tua dengan Pengendalian Dorongan Seksual}

Variabel bebas pada penelitian ini terdiri dari 2 , yaitu aktivitas dan peran orang tua. Sedangkan variabel tergantung yaitu pengendalian dorongan seksual.

Pada Tabel 4 digambarkan bahwa responden yang memiliki pengendalian dorongan seksual kurang dengan peran orang tua kurang $(52,9 \%)$, lebih besar daripada dengan peran orang tua baik $(32,9 \%)$. Uji statistik menghasilkan $p=0,048$, artinya terdapat hubungan antara peran orang tua dan pengendalian dorongan seksual.

Pesantren memiliki kegiatan yang wajib untuk diikuti santriwati, seperti kegiatan belajar mengajar, ekstrakurikuler, dan shalat wajib berjamaah di masjid. Pada Tabel 5 digambarkan bahwa responden yang memiliki pengendalian
Tabel 6. Persepsi Santri terhadap Kepadatan Aktivitas yang Diadakan Pesantren

\begin{tabular}{lcc}
\hline \multicolumn{1}{c}{ Kepadatan } & n & \% \\
\hline Tidak padat & 37 & 34,6 \\
Padat & 70 & 65,4 \\
Total & 107 & 100,0 \\
\hline
\end{tabular}

dorongan seksual kurang dengan aktivitas kurang $(28,6 \%)$, lebih kecil daripada dengan aktivitas padat $(43 \%)$. Uji statistik menghasilkan $\mathrm{p}=$ 0,178 , artinya tidak ada hubungan antara aktivitas remaja dan pengendalian dorongan seksual.

Tabel 6 menggambarkan mengenai persepsi santriwati terhadap kepadatan aktivitas yang diadakan oleh pesantren. Sebagian besar santri merasa kegiatan yang diadakan oleh pesantren itu padat $(65,4 \%)$.

\section{PEMBAHASAN}

\section{Pengendalian Dorongan Seksual Santriwati}

Masa remaja adalah periode kehidupan dengan kebutuhan perkembangan dan kesehatan yang spesifik. Masa ini juga merupakan saat untuk mengembangkan pengetahuan, keterampilan, mengelola emosi dan hubungan, dan membutuhkan kedudukan yang penting untuk melalui masa remajanya (WHO, 2018a). Salah satu permasalahan pada remaja adalah dorongan seksual yang kurang terkelola dengan baik. Setiap manusia yang normal

Tabel 4. Hubungan antara Peran Orang Tua dan Pengendalian Dorongan Seksual

\begin{tabular}{cccccccc}
\hline & \multicolumn{3}{c}{ Pengendalian Dorongan Seksual } & & \multicolumn{2}{c}{ Total } \\
\cline { 2 - 7 } Peran Orang Tua & \multicolumn{3}{c}{ Baik } & Kurang & \multicolumn{2}{c}{} \\
\cline { 2 - 7 } & $\mathbf{n}$ & $\mathbf{\%}$ & $\mathbf{n}$ & $\mathbf{\%}$ & $\mathbf{n}$ & \% \\
\hline Baik & 49 & 67,1 & 24 & 32,9 & 73 & 100 \\
Kurang & 16 & 47,1 & 18 & 52,9 & 34 & 100 \\
\hline
\end{tabular}

Tabel 5. Hubungan antara Aktivitas dan Pengendalian Dorongan Seksual

\begin{tabular}{|c|c|c|c|c|c|c|}
\hline \multirow{3}{*}{ Aktivitas } & \multicolumn{4}{|c|}{ Pengendalian Dorongan Seksual } & \multirow{2}{*}{\multicolumn{2}{|c|}{ Total }} \\
\hline & \multicolumn{2}{|c|}{ Baik } & \multicolumn{2}{|c|}{ Kurang } & & \\
\hline & $\mathbf{n}$ & $\%$ & $\mathbf{n}$ & $\%$ & $\mathbf{n}$ & $\%$ \\
\hline Padat & 45 & 57,0 & 34 & 43,0 & 79 & 100 \\
\hline Kurang & 20 & 71,4 & 8 & 28,6 & 28 & 100 \\
\hline
\end{tabular}


pasti memiliki dorongan seksual karena hal ini bersifat fitrah dan alamiah. Dorongan seksual merupakan perasaan ketertarikan secara seksual kepada orang lain yang dapat dipengaruhi oleh hormon seksual (BKKBN, 2012). Dorongan atau hasrat untuk melakukan hubungan seksual ini bukanlah hal yang tabu. Ini adalah fitrah dan dimiliki oleh setiap orang yang dianugerahkan Allah untuk manusia (Haryanto, 2015).

Walaupun peraturan di pesantren sudah didesain sedemikian ketatnya, ternyata santri masih memiliki kesempatan untuk menyalurkan dorongan seksualnya ke arah negatif (Fitriyah, Indriani dan Sulistyorini, 2013). Sebanyak 4,6\% responden yang pernah chatting dengan lawan jenis mengaku memiliki alasan keperluan organisasi dan kepentingan lainnya sehingga harus berinteraksi dengan lawan jenis. Responden lain mengaku melakukan chatting karena menyenangkan, merasa nyaman dengan lawan jenis, ingin mencoba hal baru, ingin lebih mengenal lawan jenis, dan alasan lain yang mengarah pada keinginan menyalurkan dorongan seksual. Sedangkan alasan mereka yang pernah berhubungan seksual yaitu karena diajak, larut dalam aktivitas pacaran, dan rasa ingin tahu yang tinggi. Sebagian responden juga mengaku bahwa mereka khilaf ketika melakukan aktivitas seksual.

Pesantren Y dengan karakteristik bangunan yang lebih tertutup sehingga interaksi antara santriwan dan santriwati lebih terbatas justru memiliki santriwati dengan pengalaman aktivitas seksual yang lebih banyak dibandingkan pesantren X. Santriwati di pesantren Y melakukan aktivitas berfantasi, jalan berdua, berpegangan tangan, mengelus, merangkul, memeluk, cium pipi, dan berhubungan seksual lebih besar daripada santriwati di pesantren X. Sedangkan santriwati di pesantren $X$ lebih banyak yang melakukan chatting daripada di pesantren Y.

Sebagaimana remaja pada umumnya, santriwati memiliki keingintahuan yang besar terhadap lawan jenis. Batas yang terlalu ketat ternyata tidak membuat mereka menaati aturan, namun mencari cara agar dapat memenuhi rasa penasarannya. Ketika interaksi awal dengan lawan jenis sudah terjalin, maka seseorang akan merasa nyaman sehingga ingin mencari pengalaman seksual lain yang belum pernah dilakukannya.
Dalam kehidupan beragama, iman yang baik ditandai dengan ketaatan pada ajaran agama yang baik tanpa terpengaruhi oleh kondisi apapun. Namun, ketika seorang remaja imannya sedang dalam titik yang rendah, maka ia dapat dengan mudah melakukan pelanggaran terhadap ajaran agama. Maka tidak dapat dipungkiri, masih ada santriwati yang memiliki kesempatan untuk melakukan pacaran. Diantara alasan yang terungkap ketika ditanya mengenai mengapa santriwati melakukan aktivitas seksual tertentu yaitu karena mereka saat itu sedang khilaf. Maka benarlah, ketika iman lemah, setan akan lebih menggoda agar manusia melakukan kemaksiatan.

Beberapa responden mengaku pernah melakukan berbagai aktivitas seksual hanya ketika dahulu belum bersekolah di pesantren. Dahulu saat masih bersekolah di luar pesantren, mereka belum memiliki ilmu dan iman yang cukup sehingga bebas melakukan apa yang diinginkan. Saat sudah di pesantren, mereka mulai mengenal batas-batas interaksi dengan lawan jenis sehingga mengaku sudah bertaubat dan tidak ingin mengulanginya lagi.

\section{Hubungan antara Aktivitas Remaja dan Pengendalian Dorongan Seksual}

Banyaknya waktu luang dapat membuat remaja menghabiskannya untuk berfantasi ataupun memikirkan hal-hal yang kurang baik. Maka, mengisi waktu luang adalah cara yang penting untuk mempengaruhi tindakan dan perilaku remaja. Jadi, mengarahkan remaja untuk melakukan kegiatan yang positif adalah solusi yang tepat agar terhindar dari perilaku negatif (Siregar, 2004).

Penelitian ini kurang sesuai dengan penelitian di atas. Hal yang menyebabkan variabel aktivitas dengan pengendalian dorongan seksual tidak signifikan adalah karakter dari pesantren dan santri tempat dilakukannya penelitian. Santri dibedakan menjadi 2, yaitu santri kalong dan mukim. Santri kalong hanya mengikuti kegiatan belajar-mengajar di pesantren lalu pulang sehingga tidak tinggal di pondok. Sebaliknya, santri mukim tinggal di dalam pondok. Hal ini dapat dikarenakan jarak rumah 
yang tidak memungkinkan untuk pulang-pergi setiap hari (Dzanuryadi, 2010).

Pesantren tempat dilakukannya penelitian memiliki karakteristik santri mukim sehingga santri menghabiskan waktu 24 jam di dalam pesantren. Kedua pesantren juga memiliki aktivitas wajib seperti kegiatan belajar mengajar, shalat 5 waktu berjamaah di masjid, kegiatan ekstrakurikuler, dan kegiatan hafalan Al-Quran, dan kegiatan tambahan lainnya. Sehingga, aktivitas santri juga tetap lebih padat daripada remaja yang bersekolah di sekolah umum yang hanya memiliki kegiatan wajib belajar mengajar dan kegiatan ekstrakurikuler.

Meskipun santri memiliki waktu luang, tidak semua mengisi waktunya untuk melampiaskan dorongan seksual karena ketatnya peraturan pesantren. Peraturan seperti tidak memperbolehkan santri untuk bertemu dengan lawan jenis, membawa buku berbau pornografi, keterbatasan akses gawai dan internet membuat santri menghabiskan waktu luang untuk mengerjakan tugas, olahraga, atau sekedar mengobrol dengan teman. Selain itu, pesantren hanya memperbolehkan santrinya keluar 2 pekan sekali bergantian antara santriwan dan santriwati. Jika ada santri yang ketahuan berinteraksi dengan lawan jenis maka akan diberikan hukuman.

Santriwati yang memiliki aktivitas padat ternyata ada yang memiliki pengendalian dorongan seksual yang kurang. Hal ini dikarenakan santriwati yang masuk pesantren karena terpaksa, sehingga hanya mengikuti kegiatan pesantren sebagai formalitas belaka. Ia akan mengikuti berbagai aktivitas pesantren namun tidak disertai dengan niat yang ikhlas. Ketika seseorang tidak merasa nyaman dengan berbagai peraturan yang ketat, maka dimungkinkan terjadi pemberontakan dari dalam dirinya. Hal ini ditandai dengan santriwati yang melanggar berbagai peraturan pesantren, seperti membawa gawai, buku dan majalah porno, dan kabur keluar pesantren.

\section{Hubungan antara Peran Orang Tua dan Pengendalian Dorongan Seksual}

Sebaiknya orang tua dapat dijadikan teladan oleh anak dalam berperilaku. Orang tua dapat memberikan pengajaran agama yang baik agar anak terhindar dari berbagai perilaku negatif (Nafis, 2011).

Sejalan dengan penelitian Putri, Shaluhiyah dan Prabamurti (2017), terdapat faktor yang berpengaruh terhadap perilaku seksual remaja. Faktor tersebut ada 4, yaitu adalah sikap, perilaku teman sebaya, dukungan orang tua, dan dukungan petugas kesehatan. Dukungan orang tua berperan penting untuk membentuk perilaku remaja dengan mencegah remaja berperilaku seksual negatif. Akan tetapi, peraturan pesantren dimana santri tinggal berpisah dengan orang tua bisa menjadi faktor meningkatnya dorongan seksual pada remaja karena kurangnya komunikasi antara keduanya. Maka, orang tua sebaiknya tidak merasa tabu guna berkomunikasi dengan remaja tentang seksualitas agar mereka dapat memperoleh pengetahuan yang benar (Khairunnisa, 2013).

Orang tua memiliki peran yang besar bagi remaja untuk mengambil keputusan mengenai aktivitas seksual. Kehangatan yang dibangun oleh anak dan orang tua ternyata memiliki dampak yang signifikan dalam pengendalian diri remaja putri (Kincaid et al., 2012).

Penelitian ini menunjukkan bahwa sebagian besar santri jarang bertelepon dan bertemu dengan orang tua. Hal ini dikarenakan peraturan pesantren yang membatasi santri untuk keluar kompleks pesantren dan santriwati juga tidak diperkenankan membawa gawai ke dalam asrama. Walaupun dalam keadaan terbatas seperti itu, sebagian besar santri mengaku memiliki kedekatan yang baik dengan orang tua. Kedekatan seperti ini bukan lagi mengenai jarak karena mereka hidup terpisah, akan tetapi kedekatan orang tua dan anak ini adalah kedekatan dari hati ke hati.

Orang tua yang sibuk sehingga jarang berkomunikasi secara intensif dengan anak maka dapat mengatasinya dengan bekerja sama dengan guru di sekolah. Guru diberikan otoritas untuk bisa mengarahkan anak sesuai dengan kesepakatan antara orang tua dan guru (Arifianto \& Eko, 2016). Maka, dengan menitipkan anak ke pesantren disertai dengan komunikasi yang baik dengan pengelola pesantren adalah cara yang baik agar orang tua dapat memantau perkembangan anaknya walaupun jarang bertemu. 
Pembicaraan mengenai seksualitas antara orang tua dan anak berperan penting untuk mencegah perilaku seksual remaja. Pesan tersebut dapat berisi penanaman tentang nilai moral serta cara mengendalikan dorongan seksual tepat. Anak juga diajarkan bagaimana memilih teman yang baik dan lebih berhati-hati dalam bersosial media agar terhindar dari konten pornografi (Haryani, Wahyuningsih dan Haryani, 2015). Dalam penelitian ini didapatkan bahwa santriwati masih sangat jarang yang curhat mengenai pergaulan dengan lawan jenis kepada orang tuanya. Selain karena jarang bertemu dan keterbatasan akses media komunikasi, hal ini dapat dikarenakan baik remaja maupun orang tua yang merasa tabu jika membicarakan mengenai seksualitas. Padahal, hal ini yang justru penting dilakukan agar remaja mendapatkan informasi yang benar dan bukan mendapatkannya dari sumber lain yang tidak dapat dipertanggung jawabkan.

Orang tua dengan pola asuh permisif berdampak pada remaja yang memiliki pengalaman perilaku seksual yang buruk karena orang tua cenderung memberikan kelonggaran bagi anak untuk melakukan sesuatu tanpa diberikan peringatan dan teguran jika anak dalam bahaya (Hargiyati, Hayati dan Maidartati, 2016). Orang tua harus menghilangkan pemikiran bahwa dengan anak berpacaran maka bisa menjadi penyemangat bagi anak dalam belajar. Faktanya, pacaran itu tidak membuat anak semakin semangat, justru membuat mereka kurang fokus belajar akibat waktu dihabiskan untuk memikirkan pacar mereka. Ditambah lagi jika ada masalah dalam berpacaran, maka konsentrasi untuk belajar akan terganggu (Arifianto \& Eko, 2016).

Sebagian besar santriwati tidak diperbolehkan oleh orang tuanya untuk berpacaran. Namun, sebagian besar orang tua kurang memantau aktivitas anaknya terhadap lawan jenis. Orang tua merasa sudah aman jika telah menitipkan anaknya di pesantren sehingga tidak perlu lagi khawatir dengan aktivitas anak. Padahal, walaupun seorang remaja telah bersekolah di pesantren tidak dapat dipungkiri bahwa ia juga memiliki peluang untuk melakukan aktivitas dengan lawan jenis.

Penelitian ini menunjukkan mayoritas orang tua berperan baik dalam mengarahkan anaknya untuk berada pada ketentuan agama agar tidak terlewat dalam berhubungan dengan lawan jenis. Nilai dan norma Islam adalah poin penting yang mampu menjaga remaja dari pergaulan bebas (Arifianto \& Eko, 2016). Agama mampu menjadi benteng dalam berinteraksi dengan lawan jenis. Mendekatkan remaja pada agama juga mampu berkontribusi untuk menambah kesibukan untuk beribadah ataupun terlibat pada kegiatan sosial keagamaan sehingga bertambahlah religiusnya.

Ketika santriwati berada di rumah, orang tua orang tua perlu mengawasi dalam penggunaan gawai. Berbagai acara televisi dan kemudahan akses media sosial mampu memberikan kesempatan bagi anak remaja untuk melihat konten dewasa yang belum pantas untuk mereka saksikan (Arifianto \& Eko, 2016). Orang tua sebaiknya mengawasi anak remaja mereka agar terhindar dari konten negatif. Setelah lama tinggal di pesantren dengan tanpa gawai dan keterbatasan komunikasi, anak akan merasa bebas setelah tiba liburan panjang ketika mereka bisa bersosial media sepuasnya. Jika orang tua luput, maka anak dapat bebas berinteraksi dengan lawan jenis.

Tidak hanya penggunaan gawai di rumah yang harus diperhatikan, akan tetapi peran orang tua dalam memberikan kebebasan anak untuk membawa gawai ke pesantren juga harus diperhatikan. Masih terdapat orang tua yang memperbolehkan anaknya membawa gawai ke pesantren padahal hal tersebut termasuk pelanggaran berat. Bisa juga orang tua yang tidak sadar bahwa anaknya membawa benda terlarang tersebut. Jika seorang santriwati memiliki pacar, maka ia bisa menggunakan gawai secara sembunyi-sembunyi untuk chatting atau bahkan janjian untuk bertemu dengan pacarnya.

\section{SIMPULAN DAN SARAN}

\section{Simpulan}

Uji statistik antara peran orang tua dengan pengendalian dorongan seksual didapatkan nilai ( $\mathrm{p}<0,005$ ), artinya terdapat hubungan yang signifikan. Sedangkan hasil uji statistik antara aktivitas remaja dengan pengendalian dorongan seksual tidak signifikan $(p>0,005)$. 
Aktivitas santri tetap lebih padat daripada remaja yang bersekolah di sekolah umum yang hanya memiliki kegiatan wajib belajar mengajar dan kegiatan ekstrakurikuler. Meskipun santri memiliki waktu luang, peraturan pesantren yang ketat membuat mereka terhindar dari aktivitas negatif. Peraturan seperti tidak memperbolehkan santri untuk bertemu dengan lawan jenis, membawa buku berbau pornografi, dan keterbatasan akses gawai dan internet membuat santri menghabiskan waktu luang untuk mengerjakan tugas, olahraga, atau sekedar mengobrol dengan teman.

Semakin baik peran orang tua maka pengendalian dorongan seksualnya juga semakin baik. Remaja harus dibimbing untuk berperilaku baik dan menjaga interaksi dengan lawan jenis karena pergaulan bebas adalah suatu hal yang dilarang dalam Islam. Menitipkan anak ke pesantren disertai dengan komunikasi yang baik dengan pengelola pesantren adalah cara yang baik agar orang tua dapat memantau perkembangan anaknya walaupun jarang bertemu.

\section{Saran}

Pengelola pesantren sebaiknya dapat meningkatkan komunikasi kepada santriwati dan orang tua terkait seksualitas agar santriwati dapat mengarahkannya ke aktivitas yang positif. Orang tua juga perlu diedukasi agar memiliki peran yang baik terhadap kehidupan remaja santriwati, terutama dalam menyikapi lawan jenis. Membangun komunikasi antara orang tua dengan pengelola pesantren merupakan alternatif yang baik sehingga perkembangan anak dapat dipantau walaupun jarang bertemu.

\section{DAFTAR PUSTAKA}

Arifianto, A.A., Eko, A.A., 2016. Sahabat Keluarga. [online] Jakarta: Kementerian Pendidikan dan Kebudayaan. Available at: $<$ https://sahabatkeluarga.kemdikbud.go.id/ laman/index.php? $r=$ tpost $/$ xview\&id=3554> [Accessed 2 Feb. 2019].

Aviyah, E., Farid, M., 2014. Religiusitas, Kontrol Diri dan Kenakalan Remaja. Jurnal Psikologi Indonesia, 3(2), pp.126-129.
Barnes, G.M., Hoffman, J.H., Welte, J.W., Farrell, M.P., Dintcheff, B.A., 2007. Adolescents' Time Use: Effects on Substance Use, Delinquency and Sexual Activity. Journal of Youth and Adolescence, 36(5), pp.697-710.

BKKBN, 2012. Buku Suplemen Bimbingan Teknis Kesehatan Reproduksi: Dorongan Seksual. Jakarta: UNESCO.

BKKBN, 2017. Survey Kependudukan, Keluarga Berencana, Kesehatan Reproduksi Remaja dan Pembangunan Keluarga di Kalangan Remaja Indonesia. Jakarta: BKKBN.

Dzanuryadi, M., 2010. Goes to Pesantren. Jakarta: PT. Lingkar Pena Kreativa.

El-Shafa, A., 2014. Menjadi Wanita yang Dicintai Allah. Surabaya: Pustaka Media.

EMIS, 2016. Education Management Information System. [online] Jakarta: Kementerian Agama Republik Indonesia. Available at: <http:// emispendis.kemenag.go.id/emis2016v1/ index.php?jpage $=$ QTNtaXcvS04xZ0E5dmZw UEpHb2tSQT09> [Accessed 7 Jan. 2019].

Firdausita, R.S., 2017. Pengaruh Pemahaman Agama dan Lingkungan Terhadap Perilaku Perempuan Hamil di Luar Nikah di Kecamatan Pucuk Kabupaten Lamongan. Thesis. Universitas Islam Negeri Sunan Ampel.

Fitriyah, N., Indriani, D., Sulistyorini, Y., 2013. Riwayat Kesehatan Reproduksi Remaja Santri. Jurnal Biometrika dan Kependudukan, 2(2), pp.182-192.

Hargiyati, I.A., Hayati, S., Maidartati, 2016. Hubungan Pola Asuh Orang Tua dengan Perilaku Seks Pranikah pada Remaja Usia (1518) Tahun di SMA X Kabupaten Bandung. Jurnal Ilmu Keperawatan, 4(2), pp.129-140. Haryani, D.S., Wahyuningsih., Haryani, 2015. Menyikapi Dorongan Seksual di Masa Remaja (Tinjauan Hadist Psikologi). Jurnal Ners dan Kebidanan Indonesia, 3(3), pp.140-144.

Haryanto, T., 2015. Menyikapi Dorongan Seksual di Masa Remaja (Tinjauan Hadist Psikologi). PSIKIS-Jurnal Psikologi Islami, 1(1), pp.87-94.

Kao, T.S., Salerno, J., 2014. Keeping Adolescents Busy with Extracurricular Activities. The Journal of School Nursing, 1(2), pp.57-67.

Khairunnisa, A., 2013. Hubungan Reigiusitas dan Kontrol Diri dengan Perilaku Seksual Pranika 
Remaja di MAN 1 Samarinda. eJournal psikologi, 1(2), pp.220-229.

Kincaid, C., Jones, D.J., Sterrett, E., McKee, L., 2012. A Review of Parenting and Adolescent Sexual Behavior: The Moderating Role of Gender. Clinical Psychology Review, 32(3), pp.177-188.

Kompri, 2018. Manajemen dan Kepemimpinan Pondok Pesantren. Jakarta: Prenada Media Group.

Kurniawati, Y., 2018. Perbedaan Dorongan Seksual pada Remaja yang Sekolah Berbasis Umum dan Berbasis Agama pada MAN 2 Karanganyar dan MAN Karanganyar. Skripsi. Universitas Muhammadiyah Surakarta.

Nafis, M.C., 2011. Kependudukan Perspektif Islam. Jakarta: Mitra Abadi Press.

Pujawati, Z., 2016. Hubungan Kontrol Diri dan Dukungan Orang Tua dan Perilaku Disiplin pada Santri di Pondok Pesantren Darussa'adah Samarinda. eJournal Psikologi, 4(2), pp.227236.

Putri, S., Shaluhiyah, Z., Prabamurti, P.N., 2017. Faktor-Faktor yang Berhubungan dengan Perilaku Seksual Remaja yang Tinggal di Lingkungan Resosialisasi Argorejo Kota Semarang. Jurnal Kesehatan Masyarakat, 5(1), pp.13-16.

Siregar, M., 2004. Faktor-Faktor yang Mempengaruhi Penyalahgunaan Narkotik pada Remaja: Studi Deskriptif di Panti Sosial
Pamardi Putra "Insyaf" Medan. Jurnal Ilmu Kesejahteraan Sosial Pemberdayaan Komunitas, 3(2), pp.100-105.

Supriyadi, T., 2017. Perempuan dalam Timbangan Al-Qur'an dan Sunnah (Wacana Perempuan dalam Perspektif Pendidikan Islam). In: Seminar Nasional Membangun Generasi Emas 2045 yang Berkarakter dan Melek IT dan Pelatihan Berpikir Suprarasional. Sumedang: Sumedang Press.pp.492-493.

Surbakti, E.B., 2009. Kenalilah Anak Remaja Anda. Jakarta: PT Elex Media Komputindo.

Towaf, S.M., 2008. Pendidikan Seksualitas dan Kesehatan Reproduksi Model Pesantren Bagi Remaja. Forum Kependidikan, 27(2), pp.146-159.

WHO, 2018a. Adolescent Development. [online] Available at: $<\mathrm{http}: / / \mathrm{www}$. who.int/maternal_ child_adolescent/topics/adolescence/ development/en/> [Accessed 1 Jan. 2019].

WHO, 2018b. Recognizing Adolescence. [online] Available at: $<$ http://apps.who.int/adolescent/ second-decade/section2/page1/recognizingadolescence.html $>$ [Accessed 2 Feb. 2019].

Wijayanti, A.C., Robi'i, P.H.R., 2017. Hubungan antara Sikap dan Teman Sebaya dengan Perilaku Pacaran Remaja di Kecamatan Kartasura Kabupaten Sukoharjo. Jurnal Kesehatan Masyarakat Khatulistiwa, 4(3), pp.206-211. 